\title{
質量付加と加熱をともなう 断面積一定のダクトにおける 圧縮性内部流れのモデル*1 \\ Compressible Internal Flow Model with Mass and Heat Additions in a Constant Area Duct
}

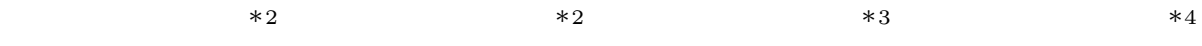 \\ Masashi Kashitani, Yutaka Yamaguchi, Yoshiaki MiYazato and Kazuyasu Matsuo
}

Key Words : Compressible Flow, Boundary Layer, Mass and Heat Additions, Choking, Flow Model

\begin{abstract}
The present paper describes a one-dimensional model for a compressible internal flow with mass and heat additions in a constant area duct taking account of the upstream boundary layer. The conservation equations across a control volume are treated one-dimensionally by assuming an appropriate mean flow. This model can estimate the maximum amount of the mass flow rate on the flow choking for a given upstream free Mach number and boundary layer thickness. As the result, a parallel injection can add more amount of mass flow rate than normal injection in the present analytical condition. The characteristics of the flow such as the down stream Mach number, static pressure and total pressure distributions are analyzed with the boundary layer thickness for given upstream condition. Also, the analytical result of the present model shows better agreement with the previous experimental data on the mass and heat additional flows in constant area duct.
\end{abstract}

\section{1. ま え がき}

高い比インパルスをもち, 極超音速飛行エンジンとして 有効と考えられているスクラムジェットエンジンは, 燃料の 付加と燃焼による加熱を超音速で行わなければならず, 燃 焼器における燃料の混合促進をはじめ, 高効率の空気取入 口とノズル, 各エンジン構造部の冷却など, エンジン成否の 重要な要素について，これまで議論が重ねられている1 3). 特に, エンジン内部流れにおいて, 燃料の付加や燃焼により 加熱された主流と，機体から生じた厚い境界層との干渉に より起こる流れの閉塞は, エンジン性能の著しい低下やエ ンジン不始動の危険性をもたらすことか指摘されており4)， 質量付加と加熱をともなう流れ場の境界層の影響を理解す ることは , 極めて重要である .

加熱による流れの閉塞つまり熱閉塞に関する実験は, 当量 比をパラメータとし流れ場の可視化や壁面静圧測定を行い， 熱閉塞が起こる過程などについて議論 $\left.{ }^{5} 8\right)$ がなされている. しかし，質量付加による流れの閉塞に関する実験は，これま で熱閉塞の実験の一部分として行われた程度である.一方， 理論解析による研究では, 複合閉塞の存在を提唱し, エン ジンに流入する非一樣流を高速と低速の二流管で代表する モデルにより，複合閉塞と熱閉塞の関係など現象の詳細が

\footnotetext{
*1 C 2003 日本航空宇宙学会

平成 15 年 2 月 4 日原稿受理

*2 防衛大学校システム工学群航空宇宙工学科

$* 3$ 九州大学大学院総合理工学研究院環境エネルギー工学専攻

${ }^{* 4}$ 北九州市立大学国際環境工学部環境機械システム工学科
}

解析されている ${ }^{9,10)}$. また, 数值流体力学による研究11 13) では, 熱閉塞が起こる過渡状態や流れの二次元および三次 元性について明らかにされている.このように，理論解析 や数値計算によって熱閉塞に関する研究が進められている が, 質量付加による流れの閉塞については，これまで非粘 性一次元解析 ${ }^{14 \sim 17)}$ が行われた程度で, 主流に対する質量 付加の方向や, 流れの閉塞と境界層の関係など詳細につい ては, 未だ不明な点が多い .

本研究では，境界層によって断面にわたり非一樣な速度 や密度分布を有し，質量付加と加熱をともなう断面積一定 管内圧縮性流れについて，一次元的に取り扱えるモデルを 提案し，質量付加をともなう流れ場の解析を中心に行い，こ れまでの実験データと比較検討する．

\section{2. 解 析 モ デル}

2.1 流れの平均化 流路断面積 $A$ にわたり流速 $u$ や密 度 $\rho$ が一樣でない流れを一次元的に取り扱うため, 平均密 度 $\bar{\rho}$ を通常の圧縮性流体力学に関するテキスト ${ }^{18,19)}$ に記載 されているように，次式で定義する．

$$
\bar{\rho} \equiv \int \rho u \mathrm{~d} A / \int u \mathrm{~d} A
$$

また, 温度 $T$, 音速 $a$, 流速 $u$ に対して, 平均温度 $\bar{T}$, 平均 音速 $\bar{a}$, 平均流速 $\bar{u}$ を断面を通る質量の重みつき平均值 ${ }^{20}$ として以下のように定義する .

$$
\bar{T} \equiv \int T \rho u \mathrm{~d} A / \int \rho u \mathrm{~d} A
$$


Mass addition

$\Delta m=\rho_{s} u_{s} S, u_{\mathrm{s}}^{\prime}=u_{\mathrm{s}} \cos \theta \quad$ Heat addition

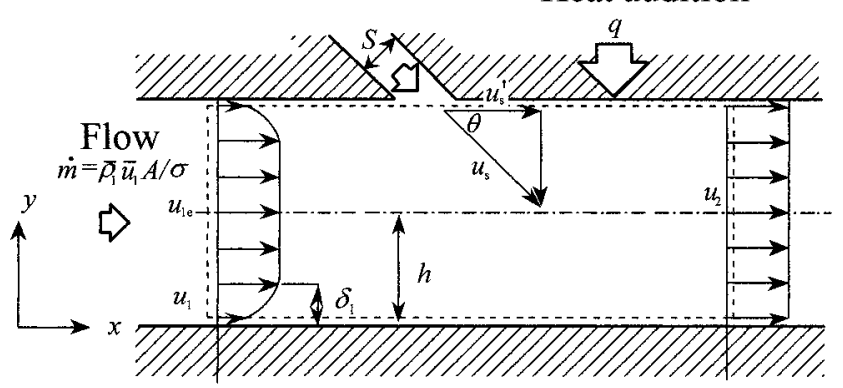

Section 1

Section 2

第 1 图 質量付加と加熱をともなう管内流れの検查体積

$$
\begin{aligned}
& \bar{a} \equiv\left(\int a^{2} \rho u \mathrm{~d} A / \int \rho u \mathrm{~d} A\right)^{1 / 2} \\
& \bar{u} \equiv\left(\int \rho u^{3} \mathrm{~d} A / \int \rho u \mathrm{~d} A\right)^{1 / 2}
\end{aligned}
$$

流路断面にわたって静圧 $p$ と全温度 $T_{0}$ を一定と仮定する と, 上式の平均化により, 完全気体の状態方程式, 等エン トロピーの関係式, エネルギー式は, 光れ㐌れ， $\bar{p}=\bar{\rho} R \bar{T}$ ， $\bar{p} / \bar{\rho}^{\gamma}=$ 一定， $C_{p} \bar{T}+\bar{u}^{2} / 2=$ 一定となる. ただし， $R$ は 気体定数, $\gamma$ は比熱比, $C_{p}$ は定圧比熱である.また，この ような平均化により，質量と運動量について以下に定義す る修正係数 $\sigma$ と $\xi$ を導入できる.

$$
\begin{aligned}
& \sigma \equiv \overline{\rho u} A / \int \rho u \mathrm{~d} A \\
& \xi \equiv \int \rho u^{2} \mathrm{~d} A / \bar{u} \int \rho u \mathrm{~d} A
\end{aligned}
$$

$\sigma$ と $\xi$ を使えば，非一樣な断面を通過する流れの保存則を， 一次元の形で記述することが可能である .

ここで, 後述の第 1 図に示す断面 1 の境界層厚さを $\delta_{1}$ で 示し, 主流の諸量に添字 $e$ を付け, 壁から流れに垂直方向 の距離を $y$ として, 次式で示す積分式 $H_{j, k, l}$ を導入する.

$$
H_{j, k, l} \equiv \int_{0}^{1}\left(\frac{\rho_{1}}{\rho_{1 e}}\right)^{j}\left(\frac{u_{1}}{u_{1 e}}\right)^{k}\left(\frac{y}{\delta_{1}}\right)^{l} \mathrm{~d}\left(\frac{y}{\delta_{1}}\right)
$$

上式 (7) と流路半値幅 $h$ を用いると，平行平板流れの断面 1 の修正係数 $\sigma_{1}$ と $\xi_{1}$ は次式で表される.

$$
\begin{aligned}
& \sigma_{1}=\frac{1}{1+\frac{\delta_{1}}{h}\left(H_{0,1,0}-1\right)}\left[\frac{1+\frac{\delta_{1}}{h}\left(H_{1,3,0}-1\right)}{1+\frac{\delta_{1}}{h}\left(H_{1,1,0}-1\right)}\right]^{1 / 2} \\
& \xi_{1}=\frac{1+\frac{\delta_{1}}{h}\left(H_{1,3,0}-1\right)}{\left[\left\{1+\frac{\delta_{1}}{h}\left(H_{1,1,0}-1\right)\right\}\left\{1+\frac{\delta_{1}}{h}\left(H_{1,3,0}-1\right)\right\}\right]^{1 / 2}}
\end{aligned}
$$

なお, 円管の修正係数は, 流路半值幅 $h$ を半径 $r$ として導

出可能である . また，断面にわたって静圧と全温度が一定 の仮定より, 断面 1 の主流マッ八数を $M_{1 e}$ とすると, 主流 と境界層内の密度比 $\rho_{1} / \rho_{1 e}$ と速度比 $u_{1} / u_{1 e}$ について, 以 下の関係が成立し ${ }^{21) ，}$

$$
\frac{\rho_{1}}{\rho_{1 e}}=\frac{1}{1+\frac{\gamma-1}{2} M_{1 e}^{2}\left\{1-\left(\frac{u_{1}}{u_{1 e}}\right)^{2}\right\}}
$$

式 (7) の積分式と式 (10) の関係式を用いると，式 (8)，(9) の $\sigma_{1}$ と $\xi_{1}$ を求めることが可能である .

2.2 流れの保存則 流れの保存則を記述するにあたり， $x, y$ 座標に対して第 1 図に示すような検査体積を考える 主流に対して質量付加と加熱が行われる直前, 直後を断面 1 , 断面 2 とし, 検査体積壁面の摩擦を無視して, 完全気体 の定常な断熱流れを仮定する. 断面 1 については厚さ $\delta_{1}$ の 境界層を考慮し, 主流と境界層内の速度比 $u_{1} / u_{1 e}$ を, 次 式に示すように $1 / n$ 乗指数法則に従うと仮定する .

$$
\frac{u_{1}}{u_{1 e}}=\left(\frac{y}{\delta_{1}}\right)^{1 / n} \quad\left(0 \leq y \leq \delta_{1}\right)
$$

また, 検査体積内の $y$ 方向の各断面内で静圧と全温度は一 定と仮定する .ここで，断面 2 の速度分布は現在よく分かっ ていないが，下流の速度分布を一樣と仮定した超音速内部 流れに発生する擬似衝撃波のモデル ${ }^{22)}$ は, 実験結果を定量 的に予測可能であることが報告されているため，本解析で も断面 2 の速度分布を一樣と仮定する。

次に，質量付加は断面積 $S$ の管路から，一樣流速度 $u_{s}$, 密度 $\rho_{s}$, 全温度 $T_{0 s}, x$ 軸に対して角度 $\theta$ て検査体積へ流 入すると仮定する .このとき検査体積へ加える質量流量は $\Delta m=\rho_{s} u_{s} S$ となり， $x$ 軸方向の速度成分は $u_{s} \cos \theta$ とな るから，質量付加によって検査体積に加える $x$ 方向の運動 量は $\Delta m u_{s} \cos \theta$ となる .ここで, $\theta=0^{\circ}$ なら断面 1 の流 れに平行な質量付加， $\theta=90^{\circ}$ なら垂直な質量付加を意味 する。

以上の仮定から，断面 1 の質量流量は平均値と修正係数 を用いて表すと $\dot{m}=\bar{\rho}_{1} \bar{u}_{1} A / \sigma$ となり，破線で囲む検査体 積について質量, 運動量, エネルギーの保存則を考えると 以下のように表される .

$$
\begin{aligned}
& \int \rho_{1} u_{1} \mathrm{~d} A+\rho_{s} u_{s} S=\rho_{2} u_{2} A \\
& \int\left(p_{1}+\rho_{1} u_{1}^{2}\right) \mathrm{d} A+\rho_{s} u_{s}^{2} S \cos \theta=\left(p_{2}+\rho_{2} u_{2}^{2}\right) A \\
& \int\left(C_{p 1} T_{1}+\frac{u_{1}^{2}}{2}+q\right) \rho_{1} u_{1} \mathrm{~d} A+C_{p s} T_{0 s} \rho_{s} u_{s} S \\
& =\left(C_{p 2} T_{2}+\frac{u_{2}^{2}}{2}\right) \rho_{2} u_{2} A
\end{aligned}
$$

ただし，添字 $1 ， 2$ は断面 $1 ， 2$ における状態，添字 $s$ は検 査体積内へ加える流れの状態, 添字 0 はよどみ状態を乥れ

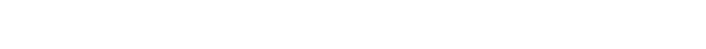

$$
p=\rho R T
$$


2.3 流れの関係式 本節では, 式 (12)〜 (15) の基礎方 程式に 2.1 節で定義した平均量 (本解析では平行平板流れ を考える） $\sigma_{1}$ と $\xi_{1}$ を用いて保存則を整理する．今，各断 面で比熱比 $\gamma$ および定圧比熱 $C_{p}$ は同じと仮定し，式 (13) を $p_{2} / p_{1}$ について整理すると

$$
\frac{p_{2}}{p_{1}}=\frac{1+\frac{\gamma \bar{M}_{1}^{2}}{\sigma_{1}}\left(\xi_{1}+N \sqrt{\frac{T_{s}}{\bar{T}_{1}}} \frac{M_{s} \cos \theta}{\bar{M}_{1}}\right)}{1+\gamma M_{2}^{2}}
$$

ただし， $\bar{M}_{1}=\bar{u}_{1} / \bar{a}_{1}$ は断面 1 の平均マッハ数， $M_{2}$ は断面 2 のマッ八数， $M_{s}$ は検査体積へ加える流れのマ ッ八数を表す. また，断面 1 と断面 $S$ の質量流量比を $N \equiv \Delta m / \dot{m}=\sigma_{1} \rho_{s} u_{s} S /\left(\rho_{1} u_{1} A\right)$ とする．なお，静温度 比 $T_{s} / \bar{T}_{1}$ と全温度比 $T_{0 s} / T_{01}$ は等エントロピーの関係よ り, $T_{s} / \bar{T}_{1}=\left\{2+(\gamma-1) \bar{M}_{1}^{2}\right\} /\left\{2+(\gamma-1) M_{s}^{2}\right\}\left(T_{0 s} / T_{01}\right)$ で表される. 次に, 加熱量と断面 1 の全エンタルピーの比 を $Q \equiv q / C_{p} T_{01}$ として, 式 (14) より断面 2 の静温度 $T_{2}$ と断面 1 の平均静温度 $\bar{T}_{1}$ の比 $T_{2} / \bar{T}_{1}$ について次式が求 まる。

$$
\frac{T_{2}}{\bar{T}_{1}}=\frac{\left(1+\frac{\gamma-1}{2} \bar{M}_{1}^{2}\right)\left(1+Q+\frac{T_{0 s}}{T_{01}} N\right)}{\left(1+\frac{\gamma-1}{2} \bar{M}_{1}^{2}\right)(1+N)}
$$

ここで, 断面 1 の主流マッ八数 $M_{1 e}$ と平均マッハ数 $\bar{M}_{1}$ の 関係は，積分式 (7) を用いると次式で示される.

$M_{1 e}^{2}$

$=\frac{2 \bar{M}_{1}^{2}}{\left\{1+\frac{\delta_{1}}{h}\left(H_{0,1,0}-1\right)\right\}^{2} \sigma_{1}^{2}\left\{2+(\gamma-1) \bar{M}_{1}^{2}\right\}-(\gamma-1) \bar{M}_{1}^{2}}$

一方，式(12)より，次式が求まるから

$$
\left(\frac{T_{2}}{\bar{T}_{1}}\right)^{1 / 2}=\frac{p_{2}}{p_{1}} \frac{M_{2}}{\bar{M}_{1}} \sigma_{1} \frac{1}{1+N}
$$

上式 (19) に式 (17) を代入し整理すると，断面 2 の静圧 $p_{2}$ と断面 1 の静圧 $p_{1}$ の比 $p_{2} / p_{1}$ は次式で示される.

$\frac{p_{2}}{p_{1}}=\sqrt{\frac{2+(\gamma-1) \bar{M}_{1}^{2}}{2+(\gamma-1) M_{2}^{2}}} \sqrt{\frac{1+\frac{T_{0 s}}{T_{01}} N+Q}{1+N}} \frac{M_{1}}{M_{2}} \frac{1}{\sigma_{1}}(1+N)$

また，式 (19) に式 (16) と式 (17) を代入し，等エントロ ピーの関係 $T_{01} / \bar{T}_{1}=1+(\gamma-1) \bar{M}_{1}^{2} / 2$ と $T_{0 s} / T_{s}=1+$ $(\gamma-1) M_{2}^{2} / 2$ を用いて整理すると，断面 2 におけるマッハ 数 $M_{2}$ は陽的に求められ，次式で示される.

$$
M_{2}^{2}=\frac{1-2 \gamma \Omega \pm \sqrt{1-2 \Omega(\gamma+1)}}{2 \gamma^{2} \Omega-(\gamma-1)}
$$

ここで, +は $M_{2}>1$, -は $M_{2}<1$ の解を示し， $\Omega$ は次 式の通りである．

$$
\Omega=\frac{(1+N)\left(1+Q+\frac{T_{0 s}}{T_{01}} N\right)\left(\bar{M}_{1}^{2}+\frac{\gamma-1}{2} \bar{M}_{1}^{4}\right)}{\left\{\sigma+\gamma \bar{M}_{1}^{2}\left(\xi_{1}+N \sqrt{\frac{2+(\gamma-1) \bar{M}_{1}^{2}}{2+(\gamma-1) \bar{M}_{s}^{2}}} \sqrt{\frac{T_{0 s}}{T_{01}}} \frac{M_{s} \cos \theta}{\bar{M}_{1}}\right)\right\}^{2}}
$$

今，流れか閉塞する条件は，式 (21) の判別式 $D=0$ より， 以下の関係が求まる.

$$
\begin{aligned}
Q= & \frac{\left\{\sigma_{1}+\gamma \bar{M}_{1}^{2}\left(\xi_{1}+N \frac{M_{s} \cos \theta}{\bar{M}_{1}} \sqrt{\frac{2+(\gamma-1) \bar{M}_{1}^{2}}{2+(\gamma-1) M_{s}^{2}}} \sqrt{\frac{T_{0 s}}{T_{01}}}\right)\right\}^{2}}{\bar{M}_{1}^{2}(1+N)(\gamma+1)\left\{2+(\gamma-1) \bar{M}_{1}^{2}\right\}} \\
& -N \frac{T_{0 s}}{T_{01}}-1
\end{aligned}
$$

上式 (23) は質量付加と加熱を考慮した流れの閉塞に関する 関係式で, マッ八数 $\bar{M}_{1}$, 全温度 $T_{01}$ の流れに対して , マッ 八数 $M_{s}$, 全温度 $T_{0 s}$, 質量流量比 $N$ の流机が断面 $S$ から 断面 1 の流れ方向に対して角度 $\theta$ で検査体積に加わるとき， 加え得る最大熱量が求められる.なお， $\sigma_{1}=1, \xi_{1}=1$ ， $N=0$ なら，レイリー流れ ${ }^{23)}$ の関係式より導出される最 大加熱量となる .

次に, $Q=0, T_{0 s}=T_{01}$ として式 (23) を $N$ について 整理すると次式を得る

$$
N=\frac{\sigma_{1}+\gamma \bar{M}_{1}^{2} \xi_{1}-\sqrt{\bar{M}_{1}^{2}\left\{2+(\gamma-1) \bar{M}_{1}^{2}\right\}(\gamma+1)}}{\bar{M}_{1} \sqrt{2+(\gamma-1) \bar{M}_{1}^{2}}\left\{\sqrt{\gamma+1}-\frac{\gamma M_{s} \cos \theta}{\sqrt{2+(\gamma-1) M_{s}^{2}}}\right\}}
$$

上式 (24) は，質量付加による流れの閉塞に関する関係式 で， $\theta$ を変化させることにより断面 1 の流れに対する質量 付加の方向を考慮することが可能である．

また，断面 1 の主流における全圧 $p_{01 e}$ と断面 2 の全圧 $p_{02}$ の比は以下のように示される .

$$
\frac{p_{02}}{p_{01 e}}=\left\{\frac{2+(\gamma-1) M_{2}^{2}}{2+(\gamma-1) M_{1 e}^{2}}\right\}^{\frac{\gamma}{\gamma-1}} \frac{p_{2}}{p_{1}}
$$

以上より質量付加と加熱をともなう，境界層の影響を考慮 した流れの閉塞に関する解析が可能となる.

\section{3．計算例および実験結果との比較}

3.1 質量付加と流れの閉塞 平行平板流れが閉塞する 最大質量付加（断面 1 と断面 $S$ の質量流量比） $N$ と主流 マッ八数 $M_{1 e}$ の関係を，主流に対する流路半值幅 $h$ で無 次元化した境界層厚さ $\delta_{1} / h$ をパラメータとして, 質量付 加の方向が $\theta=90^{\circ}$ と $0^{\circ}$ の場合について式 $(24)$ より求 め, 第 2 図 (a)，(b) に示す. 本解析では，断面 1 の全温度 


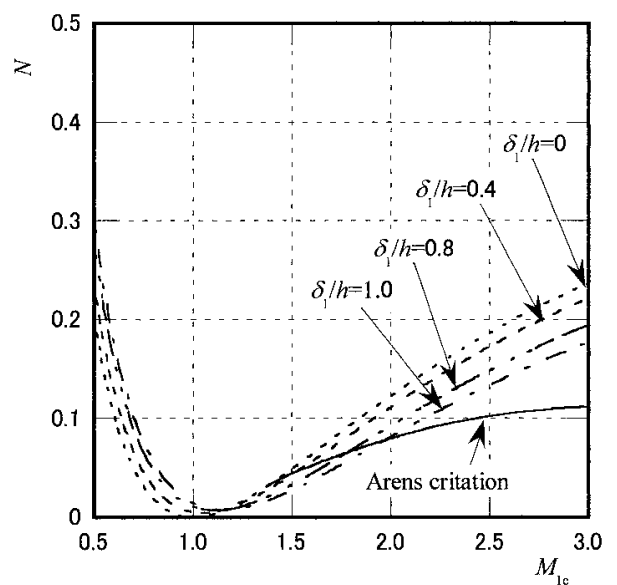

(a) $T_{0 s} / T_{01}=1.0, \theta=90^{\circ}$

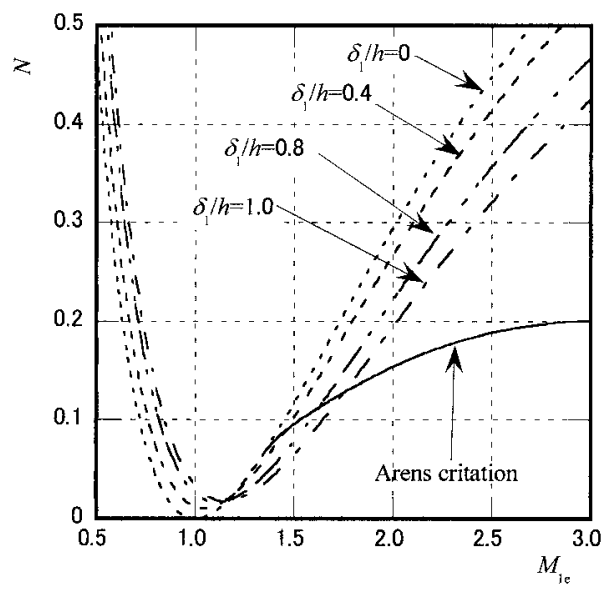

(b) $T_{0 s} / T_{01}=1.0, \theta=0^{\circ}$

第 2 図 流れが閉塞する最大質量付加

$T_{01}$ と検査体積入加える流れの全温度 $T_{0 s}$ は等しく, 比熱 比 $\gamma=1.4$, 境界層の速度分布は指数 $n=7, \theta=0^{\circ}$ のと き検査体積へ加える流れのマッハ数は $M_{s}=1.0$ として計 算した .なお，質量付加の方向が $\theta=90^{\circ}$ のとき，式 (13) の運動量の式に質量付加の運動量は影響しない，また，超 音速流れでは質量付加や加熱による逆圧力勾配によって流

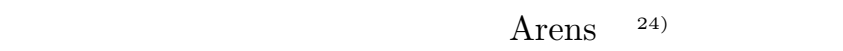
速ノズル内の乱流境界層のはく離基準圧力比 $p_{s p} / p_{1}$ より導 出される, 質量付加による流れのはく離に関する質量流量 比 $N$ と $M_{1 e}$ の関係を同時に示す $. p_{s p} / p_{1}$ は以下の式 $(26)$ で示される.

$$
\begin{aligned}
& \frac{p_{s p}}{p_{1}}=\left\{\frac{\gamma+1}{2} M_{1 e}^{2}\left(\frac{u_{1}^{*}}{u_{1 e}}\right)^{2}\right\}^{\gamma /(\gamma-1)} \\
& \times\left[1+\frac{\gamma-1}{2} M_{1 e}^{2}\left\{1-\left(\frac{u_{1}^{*}}{u_{1 e}}\right)^{2}\right\}\right]^{-1} \\
& \times\left[\frac{M_{1 e}^{2}}{2}\left\{(\gamma+1)\left(\frac{u_{1}^{*}}{u_{1 e}}\right)^{2}-\frac{(\gamma-1)^{2}}{\gamma+1}\right\}-\frac{\gamma-1}{\gamma+1}\right]^{1 /(\gamma-1)}
\end{aligned}
$$

ここで, $u_{1}^{*}$ は境界層内の特性速度， $u_{1 e}$ は断面 1 の主流速 度で実験的に $u_{1}^{*} / u_{1 e}=0.56$ と与えられる.式 $(26)$ および， 圧力係数 $C_{\text {press }}=\left(p_{s p}-p_{1}\right) / q_{1 e}=2\left(p_{s p} / p_{1}-1\right) /\left(\gamma M_{1 e}^{2}\right)$ の関係と，修正係数 $\sigma_{1}=1 ， \xi_{1}=1$ とした式 (20)より， はく離に関する $M_{1 e}$ と $N$ の関係か求められる.なお， $q_{1 e}$ は断面 1 の主流の動圧を示す .

第 2 図 (a)，(b)より，主流マッ八数 $M_{1 e}$ の流れに，垂 直または平行に質量流量を加えると流れは閉塞する．質量 付加の方向が $\theta=90^{\circ}$ の結果である第 2 図 (a) より，い ずれの $\delta_{1} / h$ でも流れが閉塞する最大質量付加 $N$ は, 主 流マッ八数 $M_{1 e}=0.5$ から $M_{1 e}$ の増加とともに急激に減 少し $M_{1 e}=1.0$ から 1.15 で最小となる. 兴の後 $M_{1 e}$ の 増加とともに $N$ も増加する . また,$\delta_{1} / h=1.0$ の最小值 $M_{1 e}=1.15$ より小さい範囲で, $M_{1 e}$ が同じなら $\delta_{1} / h$ が大 きくなると $N$ は大きくなる .一方， $M_{1 e}=1.15$ より大き い範囲で， $M_{1 e}$ が同じなら $\delta_{1} / h$ が大きくなると $N$ は小さ くなる．また，求められた $N$ より多くの質量流量を検査体 積に加えると，流れの条件は崩れ上流の状態湾化する.次 に，境界層厚さを考慮しない非粘性解析の結果 ${ }^{14)}$ は, いず れのマッハ数でも流れが閉塞する前にはく離することが示 されている.しかし, 本モデルによる計算結果と Arens ら によるはく離基準線の比較より， $M_{1 e}$ が 1.96 以下で $\delta_{1} / h$ が大きくなると，はく離基準線が最大質量付加 $N$ より大き くなる場合があり， $\delta_{1} / h$ の影響で流れがはく離する前に閉 塞すると考えられる . なお，はく離基準線の開始点は, 式 (20) に下流マッ八数 $M_{2}=1.0$ の条件を代入して求められ, $M_{1 e}=1.37, N=0.030$ である.

質量付加の方向が $\theta=0^{\circ}$ ，つまり断面 1 の流れに対して 平行に質量流量を加えたときの結果を第 2 図 (b) に示す. 図 より $N$ は $M_{1 e}$ の増加とともに, 第 2 図 (a) の $\theta=90^{\circ}$ の 結果より急激に減少し $M_{1 e}=1.0$ から 1.15 の範囲で最小 となる . このとき，境界層厚さが $\delta_{1} / h=1.0$ なら $N$ の最 小值は 0.017 となり， $\theta=90^{\circ}$ の最小値 0.007 より大きい． 兴の後, $M_{1 e}$ の増加とともに $N$ も急激に増加している.こ のように, $M_{1 e}$ に対する $N$ と $\delta_{1} / h$ の関係は $\theta=90^{\circ}$ の場 合と同樣の傾向であるが, $M_{1 e}$ と $\delta_{1} / h$ が同じなら,$\theta=0^{\circ}$ は $\theta=90^{\circ}$ より $N$ の值が大きく，より多くの質量流量を 検査体積に加えることが可能である．流れのはく離につい ても $\theta=90^{\circ}$ と同樣の傾向で $\delta_{1} / h$ の影響により， $M_{1 e}$ に 対して流れがはく離する前に，質量付加によって流れか閉 塞する場合が考えられる．また，はく離基準より求まる質 量付加 $N$ は, 第 2 图 (a) に示す $\theta=90^{\circ}$ の計算結果より いずれの $M_{1 e}$ でも大きい. 第 2 图 (b) のはく離開始点は， $M_{1 e}=1.34, N=0.064$ である.

3.2 流れの諸量 $\left(\boldsymbol{\theta}=\mathbf{9 0 ^ { \circ }}\right.$ の場合） 本モデルにより検 査体積に加える流れの方向が $\theta=90^{\circ}$ のとき, 流れの諸量 と境界層厚さ $\delta_{1} / h$ の関係を, 主流マッ八数が $M_{1 e}=0.5$ お よび $M_{1 e}=3.0$ について計算し，第 3 図 (a)〜 (c) および第 4 図 (a) (c) に示す. 本解析では各断面の定圧比熱 $C_{p}=$ 一定, 比熱比 $\gamma=1.4$, 上流境界層の速度分布指数 $n=7$, 断面 1 の全温度 $T_{01}$ と検査体積に加える流れの全温度 $T_{0 s}$ 


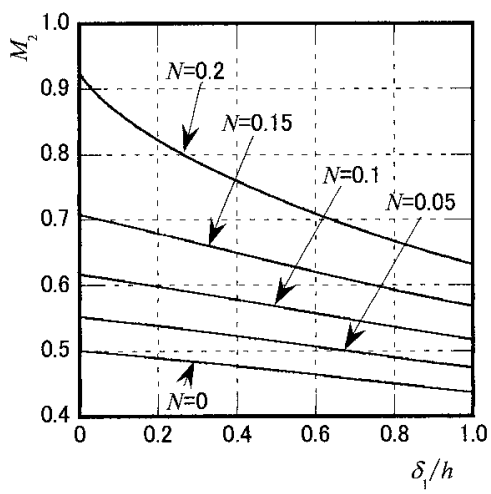

(a) 下流マッ八数

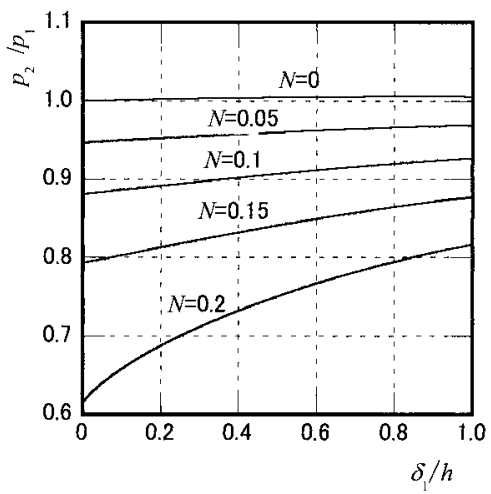

(b) 静圧比

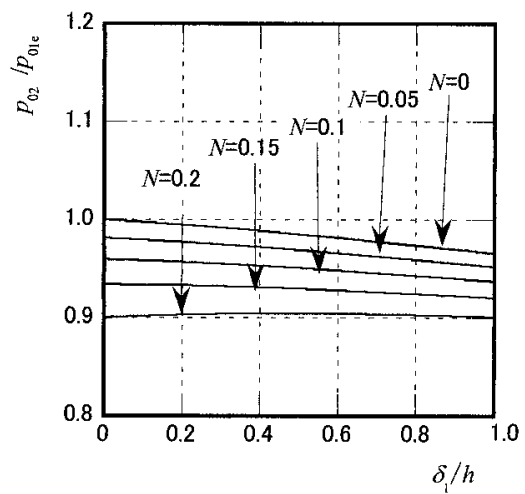

(c) 全圧比

第 3 図 質量付加をともなう流れの諸量と境界層厚さの関係 $\left(M_{1 e}=\right.$ $\left.0.5, \theta=90^{\circ}\right)$

の比 $T_{01} / T_{0 s}=1.0$ として計算を行った .なお，垂直に質 量流量を加える場合， $\theta=90^{\circ}$ より式 (13)の運動量の式に 質量付加の運動量は影響しない . 各図の横軸は , いずれも 上流境界層厚さ $\delta_{1}$ と平板高さ $h$ の比 $\delta_{1} / h$ である . 縦軸は

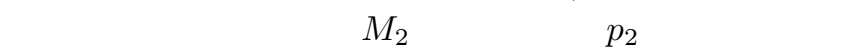
$p_{1}$ の比 $p_{2} / p_{1}$, 下流の全圧 $p_{02}$ と上流の主流全圧 $p_{01 e}$ の比 $p_{02} / p_{01 e}$ である.いずれの計算も断面 1 と断面 $S$ の質量流 量比 $N$ をパラメータとしてある.

第 3 図 (a)より $\delta_{1} / h$ の増加とともに $M_{2}$ は単調に減少 し， $N$ の増加とともに兴の割合は大きくなる.第 2 図 (a) より $\delta_{1} / h=0$ なら $N=0.23$ で流れは閉塞する . また，質 量流量を加えない $N=0$ の場合, 上流境界層厚さ $\delta_{1} / h$ の 影響で, 下流のマッ八数 $M_{2}$ は 0.5 から 0.44 まで減少す

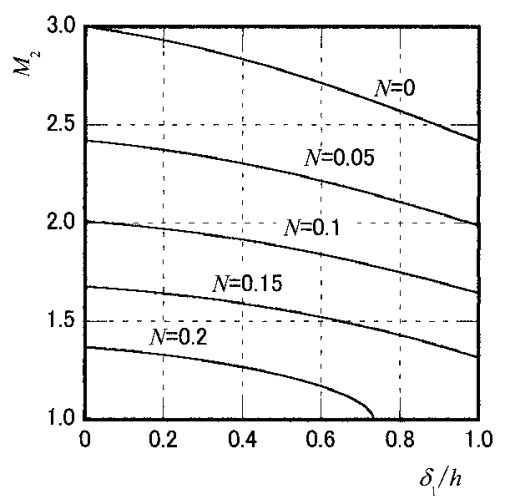

(a) 下流マッ八数

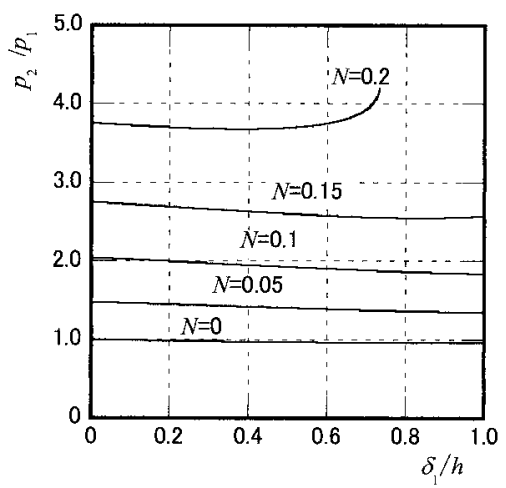

(b) 静㽵比

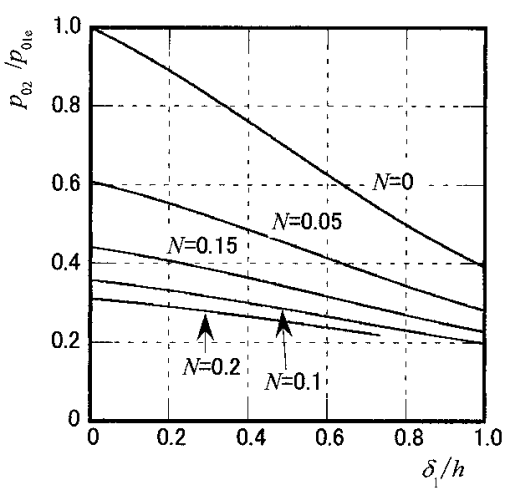

(c) 全圧比

第 4 図 質量付加をともなう流れの諸量と境界層厚さの関係 $\left(M_{1 e}=\right.$ $\left.3.0, \theta=90^{\circ}\right)$

る.次に，第 3 図 (b) の静圧比 $p_{2} / p_{1}$ について, $N=0$ の とき， $\delta_{1} / h$ に対して $p_{2} / p_{1}$ はほぼ一定であるが， $N$ を大 きくすると $p_{2} / p_{1}$ は小さくなる . また , いずれの $N$ でも $p_{2} / p_{1}$ は $\delta_{1} / h=0$ のとき最も小さく,$\delta_{1} / h$ の増加ととも に増加する. 第 3 図 (c) より, $p_{02} / p_{01 e}$ は $\delta_{1} / h$ の増加と ともに $N=0,0.05,0.1,0.15$ で単調に減少する.一方， $N=0.2$ のとき $p_{02} / p_{01 e}$ は $\delta_{1} / h$ の増加とともに若干では あるか増加したのち減少する.これは，第 3 図 (a)，(b) お よび式 $(25)$ より $\delta_{1} / h$ による $M_{2}$ の減少と, $p_{2} / p_{1}$ の増加 の影響である .

次に $M_{1 e}=3.0$ の計算結果である，第 4 図 (a)〜 (c) につ いて考える. 第 4 図 (a) より $M_{2}$ は $\delta_{1} / h$ ，および $N$ の増 加とともに単調に減少し, $N=0.2$ のとき, $\delta_{1} / h=0.74$ 


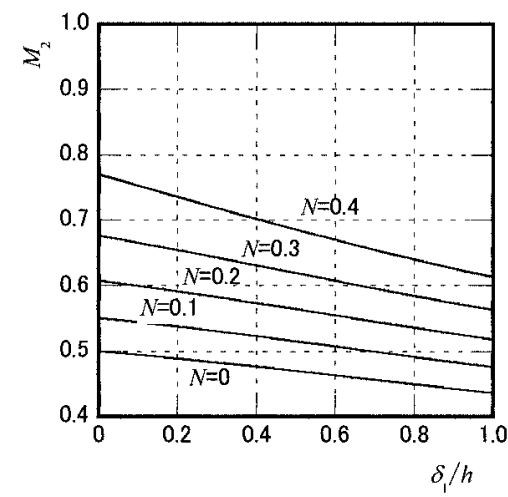

(a) 下流マッ八数

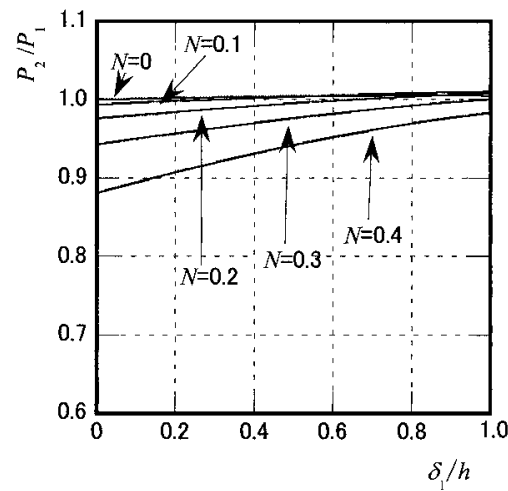

（b）静压比

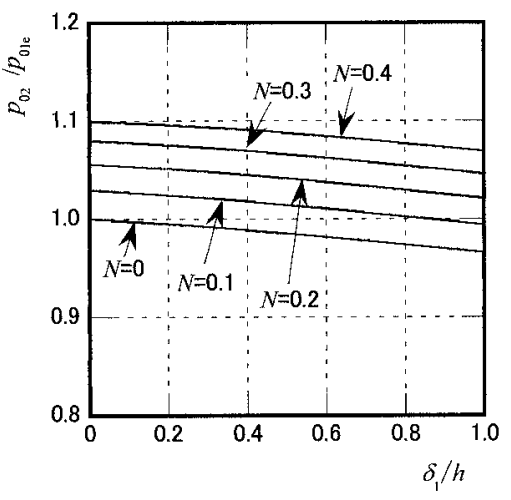

(c) 全压比

第 5 図 質量付加をともなう流れの諸量と境界層厚さの関係 $\left(M_{1 e}=\right.$ $0.5, M_{s}=1.0, \theta=0^{\circ}$ )

で流れは閉塞する、第 4 図 (b) より $p_{2} / p_{1}$ は，第 3 図 (b) と同樣 $N=0$ のときほぼ一定である . また， $N=0.2$ を 見ると, $\delta_{1} / h$ の増加により $p_{2} / p_{1}$ は単調に減少した後，流 れが閉塞する直前で急激に大きくなる.最後に第 3 图 (c) より, $p_{02} / p_{01 e}$ は $\delta_{1} / h$ の増加とともに減少し, $N=0$ で 弚の割合は最も大きい .

以上より， $M_{1 e}=0.5$ および $M_{1 e}=3.0$ いずれの場合 も， $M_{2}$ は, $N$ と $\delta_{1} / h$ のどちらの影響も強く受ける.また , $p_{2} / p_{1}$ は $N$ が大きいほど $\delta_{1} / h$ の影響を受け,$p_{02} / p_{01 e}$ は $N$ が小さいほど $\delta_{1} / h$ の影響を受ける .

3.3 流れの諸量 $\left(\boldsymbol{\theta}=\mathbf{0}^{\circ}\right.$ の場合） 検査体積に加える 流机方向が $\theta=0^{\circ}$ のとき, $M_{1 e}=0.5$ と $M_{1 e}=3.0$ に ついて解析を行い, 第 5 図 (a)〜 (c) および第 6 図 (a)〜 (c)

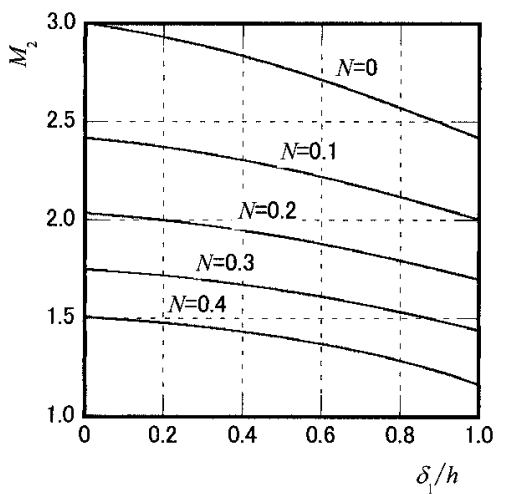

(a) 下流マッ八数

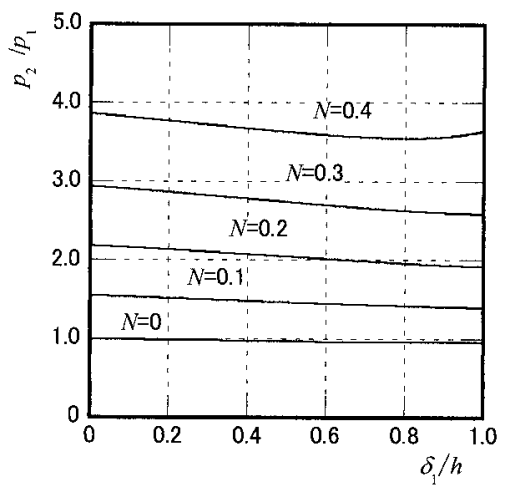

(b) 静圧比

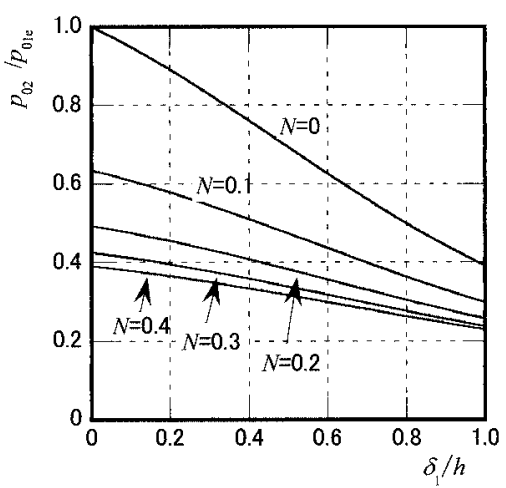

(c) 全圧比

第 6 図 質量付加をともなう流れの諸量と境界層厚さの関係 $\left(M_{1 e}=\right.$ $\left.3.0, M_{s}=1.0, \theta=0^{\circ}\right)$

に示す.計算条件は第 3,4 图と同じで, 検査体積へ加える 流れのマッハ数は $M_{s}=1.0$ とした . また , 各図の座標は 第 3, 4 图と同じで, $N$ をパラメータとして $\delta_{1} / h$ に対し $M_{2}, p_{2} / p_{1}, p_{02} / p_{01 e}$ の計算結果である.

第 5 図 (a) には $M_{1 e}=0.5$ の $M_{2}$ の解析結果を示す. 図 より $M_{2}$ は定性的に第 3 図 (a) と同樣の傾向であり，いず れの $N$ でも $\delta_{1} / h$ の増加とともに $M_{2}$ は単調に減少する また，第 3 図 (a) の $\theta=90^{\circ}$ の結果と比較して， $\delta_{1} / h$ と $M_{2}$ が同じなら，おおよ光 2 倍程度の質量流量を検査体積 に加えることが可能である . 次に第 5 图 (b) よりいずれの $\delta_{1} / h$ でも $p_{2} / p_{1}$ に対する $N$ の影響は $\theta=90^{\circ}$ の場合より 小さい，このことからも，垂直に質量流量を加える場合よ り，多くの質量流量を検査体積に加えることが可能である 


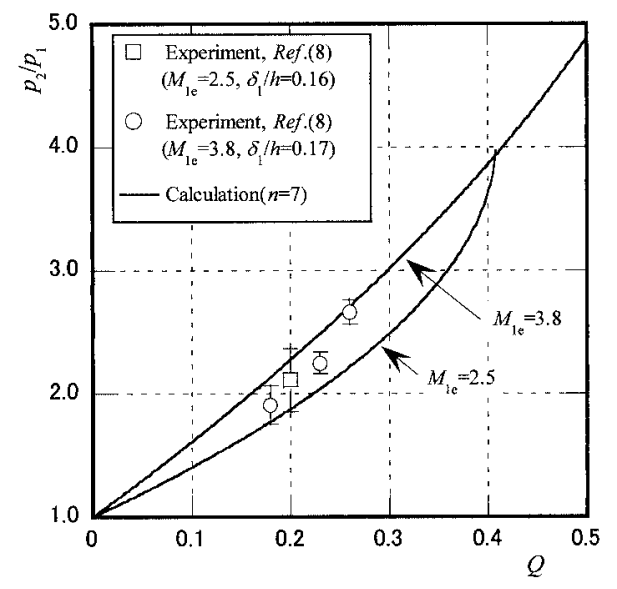

（a）加熱をともなう流れ

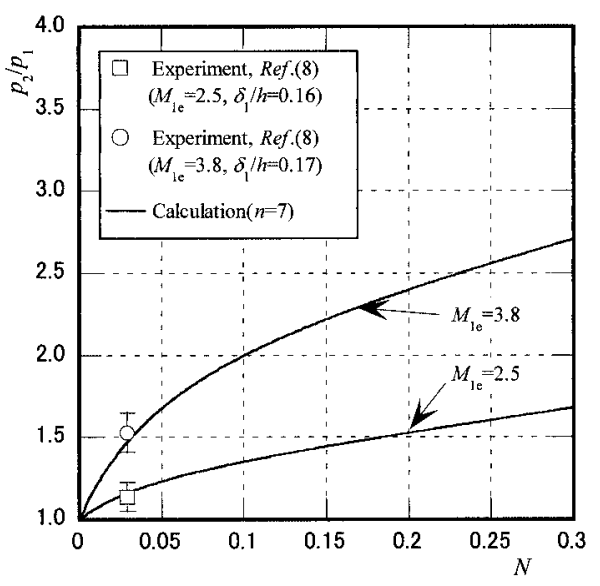

（b）質量村加をともなう流れ

第 7 図 静圧比に関する本モデルによる計算值と実験結果との比較

ことが分かる.第 5 図 (c) より, $p_{02} / p_{01 e}$ は, $\delta_{1} / h$ の増加 とともに単調に減少する.また， $\delta_{1} / h=0, N=0.49$ で流 れか閉塞するとき $p_{02} / p_{01 e}=1.11$ となり， $p_{02} / p_{01 e}=1.0$ より大きい .これは, 式 (13) に示されるように, 検査体積 へ加える流れの運動量が影響している．

最後に $M_{1 e}=3.0, \theta=0^{\circ}$ の結果について考察する . 第 6 図 (a)より $\delta_{1} / h$ ，および $N$ の増加とともに $M_{2}$ は単 調に減少し, 第 2 図 (b) から流れか閉塞する最大質量付加 は, $\delta_{1} / h=0$ のとき $N=0.57$ で, $M_{1 e}=0.5$ の結果と 同樣 $\theta=90^{\circ}$ のおおよ光 2 倍程度の質量流量を検査体積に 加えることが可能である.第 6 図 (b) , (c) の $p_{2} / p_{1}$ および $p_{02} / p_{01 e}$ は定性的に第 4 図 (b) , (c) と同樣の傾向である .

以上より，検査体積に加える流れのマッ八数 $M_{s}=1.0$ として，質量付加の方向 $\theta$ 以外を同じ条件で計算すると， $\theta=0^{\circ}$ の計算結果は, $\theta=90^{\circ}$ の結果と定性的に同樣の傾 向である.このとき, $\theta=0^{\circ}$ は $\theta=90^{\circ}$ より多くの質量流 量を検査体積に加えることが可能である .

3.4 実験結果との比較 本節では断面積一定の測定部 の流れに対して平行な質量付加と加熱をともなう従来の実 験結果 ${ }^{8)}$ と，本モデルによる計算結果を比較検討する．前 述のように境界層が質量付加や加熱をともなう流れに及ぼ す影響について，系統的な実験はこれまで行われていない．

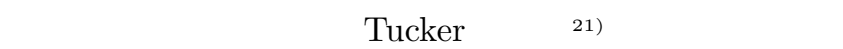
厚さ $\delta_{1} / h$ を見積もり，加熱量 $Q$ と質量流量比 $N$ に対す る上流静圧 $p_{1}$ と下流静圧 $p_{2}$ の比 $p_{2} / p_{1}$ を, 本解析結果と の比較で第 7 図 (a)，(b) に示す.なお， $N$ は当量比より， $Q$ は燃焼効率より下流の全温度を算出し加熱のみが行われ たと仮定して求めた．第 7 図 (a)の実線は, 主流マッハ数 $M_{1 e}=2.5$ と 3.8 について実験条件より求めた $\delta_{1} / h$ を代 入し，検査体積に対して加熱が行われたときの本モデルに よる計算結果を示す．また，第 7 図 (b) の実線は同樣に質 量付加が行われたときの計算結果を示す.計算では比熱比 $\gamma$ を一定とし, 各断面の定圧比熱 $C_{p}$ の違いを考慮して計 算した . 実験点 $p_{2} / p_{1}$ は, 測定部の流れに対して質量付加 や加熱が行われ壁面静圧が一定と考えられる值の平均值を 示し, 平均值からのずれも示す.

本モデルによる計算の妥当性については，より多くの実 験結果との比較が必要と考えられるが，第 7 图 (a) より， $M_{1 e}=3.8, N=0$ の場合， $Q$ について $p_{2} / p_{1}$ の実験結果 と本解析は比較的よく一致し， $Q$ の増加とともに $p_{2} / p_{1}$ も 大きくなる . また, $M_{1 e}=2.5, N=0$ の実験結果は変動 が大きく, 計算結果は実験値よりやや小さい，一方，第 7 図 (b) の $M_{1 e}=2.5,3.8$ で $Q=0$ の場合，いずれのマッ 八数でも本モデルより求められた $p_{2} / p_{1}$ の増加の割合は, $N$ の増加とともにしだいに小さくなる . また,$Q=0$ の本 モデルによる計算結果は, 実験值と定量的によく一致して いる。

\section{4. 結論}

境界層によって断面にわたり非一樣な速度や密度分布を 有し，質量付加や加熱をともなう断面積一定管内圧縮性流 れについて，一次元的に取り扱えるモデルを提案し，これ までの実験データと比較検討を行った．乥の結果を要約す ると以下の通りである .

(1) 本解析モデルによって, 上流境界層の影響を考慮した 質量付加と加熱をともなう下流のマッハ数 $M_{2}$ は, 式 (18) で与えられ, 上流静圧 $p_{1}$ と下流静圧 $p_{2}$ の比 $p_{2} / p_{1}$ は式 (20) より導出できる . また, 上流の主流における全圧 $p_{01 e}$ と下流の全圧 $p_{02}$ の比 $p_{01 e} / p_{02}$ は式 (25) で表される . 検 査体積に質量流量を加えたとき，流れが閉塞する最大質量 付加 $N$ は式 (24) で表され, 本解析では検査体積へ加える 流れの方向を考慮することが可能である．

(2) 主流に対して垂直および平行に質量流量を加えたと き，流れが閉塞する最大質量付加 $N$ は， $M_{1 e}$ の増加とと もに急激に減少し最小となった後, $M_{1 e}$ の増加とともに増 加する . また，境界層厚さ $\delta_{1} / h$ の最小値より小さい範囲で は, $M_{1 e}$ が同じなら $\delta_{1} / h$ が大きくなると $N$ は大きくなる 一方，最小值より大きい範囲では， $M_{1 e}$ が同じなら $\delta_{1} / h$ が大きくなると $N$ は小さくなる .

(3) 本モデルによる計算から，主流に対して垂直および 平行どちらに質量流量を加えても，境界層厚さ $\delta_{1} / h$ の影 響で流れがはく離する前に閉塞する場合がある。

(4) 垂直質量付加 $\left(\theta=90^{\circ}\right)$ と平行質量付加 $\left(\theta=0^{\circ}\right)$ 
について,$M_{1 e}=0.5$ と $M_{1 e}=3.0$ いずれの場合も , $M_{2}$ は $N$ と $\delta_{1} / h$ どちらの影響も強く受け, $p_{2} / p_{1}$ は $N$ が大き いほど $\delta_{1} / h$ の影響を, $p_{02} / p_{01 e}$ は $N$ が小さいほど $\delta_{1} / h$ の影響を受ける .また , 検査体積に加える流れのマッハ数 $M_{s}=1.0$ として, 質量付加の方向 $\theta$ 以外を同じ条件で計

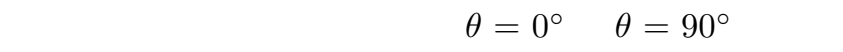
くの質量流量を検査体積に加えることが可能である .

(5) 本モデルによる計算結果は, 質量付加および加熱を ともなう流れについて従来の実験結果と比較的よく一致す る.特に, 質量付加をともなう流れの解析結果は, 定量的 にも実験結果と良く一致する．

\section{参 考 文 献}

1) J. L. ケルブロック：ジェットエンジン概論，梶昭次郎訳，東京 大学出版会, 東京, 1993, pp. 395-445.

2) Curran, E. T., Heiser, W. H. and Pratt, D. T.: Fluid Phenomena in Scramjet Combustion Systems, Annu. Rev. Fluid Mech., 28 (1996), pp. 323-360.

3) Ferri, A.: Review of SCRAMJET Propulsion Technology, J. Aircraft, 5 (1968), pp. 3-10.

4) Lewis, M. J. and Hastings, D. E.: The Influence of Flow NonUniformities in Air-Breathing Hypersonic Propulsion Systems, AIAA Paper 87-2079, 1987.

5) Yoon, Y., Donbar, J. M., Huh, H. and Driscoll, J. F.: Measured Supersonic Flame Properties: Heat-Release Patterns, Pressure Losses, Thermal Choking Limits, J. Propul. Power, 12 (1996), pp. 718-723.

6) McIntyre, T. J., Houwing, A. F. P., Palma, P. C., Rabbath, P. A. B. and Fox, J. S.: Optical and Pressure Measurements in Shock Tunnel Testing of a Model Scramjet Combustor, J. Propul. Power, 13 (1997), pp. 388-394.

7) O'Byrne, S., Doolan, M., Olsen, S. R. and Houwing, A. F. P.: Analysis of Transient Thermal Choking Processes in a Model Scramjet Engine, J. Propul. Power, 16 (2000), pp. 808-814.

8) O'Byrne, S., Doolan, M., Olsen, S. R. and Houwing, A. F. P.: Measurement and Imaging of Supersonic Combustion in a Model Scramjet Engine, ISSW21 Paper 2890, 1997.

9) 佐藤哲也 , 梶昭次郎 : スクラムジェットエンジンの複合閉塞によ る不始動遷移に関する数値解析 (第 1 報), 日本航空宇宙学会誌, 41 (1993), pp. 27-35.

10）佐藤哲也，梶昭次郎：スクラムジェットエンジンの複合閉塞によ る不始動遷移に関する数値解析 (第 2 報), 日本航空宇宙学会誌, 41 (1993), pp. 36-42.

11) Kim, J. and Namba, M. : Thermal Choking in ThreeDimensional Scramjet Engine Models, Trans. Jpn. Soc. Aeronaut. Space Sci., 41 (1998), pp. 155-162.

12) McDaniel, K. S. and Edwards, J. R.:Three-Dimensional Simulation of Thermal Choking in a Model Scramjet Combustor, AIAA Paper 2001-0382, 2001.

13) McDaniel, K. S. and Edwards, J. R.: Simulation of Thermal Choking in a Model Scramjet Combustor, AIAA Paper 99-3411, 1999.

14) Heiser, W. H., McClure, W. B. and Wood, C. W.: Simulating Heat Addition via Mass Addition in Constant Area Compressible Flows, AIAA J., 33 (1994), pp. 167-171.

15) Heiser, W. H., McClure, W. B. and Wood, C. W.: Simulating Heat Addition via Mass Addition in Variable Area Compressible Flows, AIAA J., 34 (1995), pp. 1076-1078.

16) Zucrow, M. J.: Gas Dynamics, John Wiley, New York, 1967, pp. $462-473$.

17) Shapiro, A. H. and Hawthorne, W. R.: The Mechanics and Thermodynamics of Steady One-Dimensional Gas Flow, J. Appl. Mech., 14 (1947), pp. 317-366.

18）生井武文, 松尾一泰: 圧縮性の流体力学, 理工学社, 東京, 1977, p. 51.

19) Ward-Smith, A. J.: Internal Fluid Flow, Clarendon Press, Oxford, 1980 , p. 67

20)鳥住保博 : 管内圧縮性流れの一次元的取扱い手法, 日本機械学会 論文集 B 編， 58 (1992), pp. 1650-1653.

21) Tucker, M.: Approximate Calculation of Turbulent Boundary-Layer Development in Compressible Flow, NACA Tech. Note 2337, 1951.

22）宮里義昭，松尾一泰: 断面積一定の管内における擬似衝撃波の一次 元モデル，日本機械学会論文集 B 編 , 61 (1995)，pp. 4359-4365.

23) 松尾一泰: 圧縮性流体力学, 理工学社, 東京, 1994, pp. 178-182.

24) Herbert, M. V. and Herd, R. J.: Boundary-Layer Separation in Supersonic Propelling Nozzles, ARC, R\&M 3421, 1964. 